\title{
Searching for the Scottish Late Upper Palaeolithic: A case study from Nethermills Farm, Aberdeenshire
}

\author{
Torben Bjarke Ballin ${ }^{1}$, Caroline Wickham-Jones ${ }^{2}$ \\ 1. Lithic Research, Stirlingshire, Scotland, U.K. and University of Bradford, Bradford, England, U.K. \\ Email: lithicresearch@btinternet.com \\ 2. University of Aberdeen, Scotland, U.K. Email: c.wickham-jones@abdn.ac.uk
}

\begin{abstract}
:
In connection with the recent examination, cataloguing and discussion of approximately 30,000 mainly Mesolithic lithic artefacts from Nethermills Farm at Banchory in Aberdeenshire, Scotland, excavated by the late James Kenworthy in the late 1970s and early 1980s, a small number of finds were identified as almost certainly whole or fragmented Late Upper Palaeolithic lithic artefacts, and others as pieces likely to date to this period. The Nethermills flint objects add to a growing list of Late Upper Palaeolithic sites and implements identified across Scotland, including tanged and other points, scrapers, and truncated pieces from Howburn in South Lanarkshire and Kilmelfort Cave on the Scottish west-coast, as well as tanged and other points from the Western and Northern Isles, with eastern Scotland so far having yielded none. On the basis of this case study, the authors suggest an approach for the continued search for Late-Glacial settlers in Scotland in general, as well as for further investigation of the large Nethermills Farm assemblage. The proposed approach suggests that we focus not only on diagnostic tool forms (in particular, tanged and backed points), which have been the focus of Scottish Late Upper Palaeolithic research thus far, but also include other chronologically significant elements, such as diagnostic technological attributes and full operational schemas.
\end{abstract}

Keywords: Scotland; lithic artefacts; Late Upper Palaeolithic; Mesolithic; methodology

\section{Introduction}

A few decades ago, the earliest lithic finds known from Scotland were a small number of assemblages dated to the mid-late ninth millennium BCE (e.g., Cramond, Saville 2008), while a Late Upper Palaeolithic (LUP) presence was only suggested by three sketches of possible tanged points in a paper by Livens (1956). The situation was exacerbated by the fact that shortly after Livens' publication the pieces vanished, with the result that until recently the question of a Scottish Upper Palaeolithic has been treated with some skepticism. In the present paper, the Late Upper Palaeolithic is defined, following Pettitt (2008) and Pettitt \& ISSN: 2055-0472. URL: http://journals.ed.ac.uk/lithicstudies/

This work is licensed under a Creative Commons Attribution 2.5 UK: Scotland License. 
White (2012), as the period from the beginning of the Late Glacial amelioration to the beginning of the Holocene, and in Scotland embracing the Hamburgian, Federmessergruppen and Ahrensburgian industries, as well as possibly elements linked to the Scandinavian Fosna Hensbacka Culture (Ballin \& Bjerck 2016). At the present time, the only Creswellian object recovered in Scotland is the angle-backed point from Fairnington in southern Scotland (Saville 2004: fig. 10.23), which the late Alan Saville (personal communication, May 2014) described as 'dubious'. We have chosen to apply north-west European terminology (names of industries), as the Scottish industries show the closest parallels with those directly across the now sub-merged Doggerland basin (Ballin 2016) (Table 1).

Table 1. The lithic industries identified in Scotland and sites mentioned in the text. Dates largely according to Sonia Grimm (personal communication, September 2016).

\begin{tabular}{|c|c|c|c|}
\hline Lithic industry & Onset cal BCE & Scottish assemblages & References \\
\hline Early Mesolithic & 9,800 & & \\
\hline \multirow[t]{4}{*}{ Ahrensburgian } & 10,800 & Brodgar, Orkney & Ballin \& Bjerck 2016 \\
\hline & & Tiree, Inner Hebrides & Ballin \& Saville 2003 \\
\hline & & Shieldaig, Loch Torridon & Ballin \& Saville 2003 \\
\hline & & Rubha Port an t-Seilich, Islay & Mithen et al. 2015 \\
\hline Federmesser-Gruppen & 12,000 & Kilmelfort Cave, Highland & Saville \& Ballin 2009 \\
\hline Hamburgian & 12,700 & Howburn & Ballin et al. 2010 \\
\hline
\end{tabular}

The recognition and publication of a number of typo-technologically certain preMesolithic pieces and assemblages from the 1990's onwards has served to build the case for LUP activity in Scotland, and recently two of the pieces described by Livens have resurfaced (one piece discussed in Ballin \& Bjerck 2016); the other piece is presently being prepared for publication by H. Anderson-Whymark, University of York (personal communications with Hugo Anderson-Whymark, November 2015). The recent finding of a further piece among the material from an old excavation at Nethermills Farm (Wickham-Jones et al. in press), has prompted this note.

While absolute dates have yet to be obtained, these typo-technologically diagnostic early pieces and assemblages have all been dated by formal comparison with contemporary northwest European material, and taken together they confirm that it may be 'proven beyond reasonable doubt' that Scotland was visited or settled by human groups in the Hamburgian (Howburn, South Lanarkshire; Ballin et al. 2010), the Federmesser-Gruppen (Kilmelfort Cave; Saville \& Ballin 2009), and Ahrensburgian periods (Tiree and Shieldaig; Ballin \& Saville 2003). The rediscovered pieces described by Livens were originally found on Orkney, and conform to types generally known from the Scandinavian Ahrensburgian and Early Mesolithic period (single-edged points and squat tanged points from the Fosna-Hensbacka period; Ballin \& Bjerck 2016).

Confirmation of such early human activity in Scotland is particularly exciting and opens the field for further research. In this respect it is worth noting that other potentially LUP assemblages are currently under investigation, such as that published by Mithen and colleagues from Rubha Port an t-Seilich, Islay (Mithen et al. 2015). A possible tanged point of LUP affinity has recently been recovered from this site (personal communications with Karen Wicks, August 2016).

Not surprisingly, the Scottish pieces so far identified as typo-technologically diagnostic LUP implements find their closest parallels in well-known north-west European Continental industries. Local developments, if they existed, have yet to be recognised. The presence of 
identifiable pieces in Scotland can only be understood on the basis of the existence of the socalled 'Doggerland Continent' (now covered by the North Sea), which we assume was inhabited by early prehistoric hunter-gatherers and which served as a springboard for settlement in this country (Fitch et al. 2007; Sturt et al. 2013; Ballin 2016). Existing finds cover Scotland from the south (e.g., Howburn) to the north (Orkney) and west (Tiree) (Figure 1) suggesting that numerous sites once existed both within Scotland and within Doggerland towards north-west Europe and Scandinavia. We contend that if the (understandable) skepticism, which has characterized Scottish early prehistoric research over the last decades was set aside, it should be possible to identify further typo-technologically diagnostic LUP elements in new as well as old lithic assemblages.

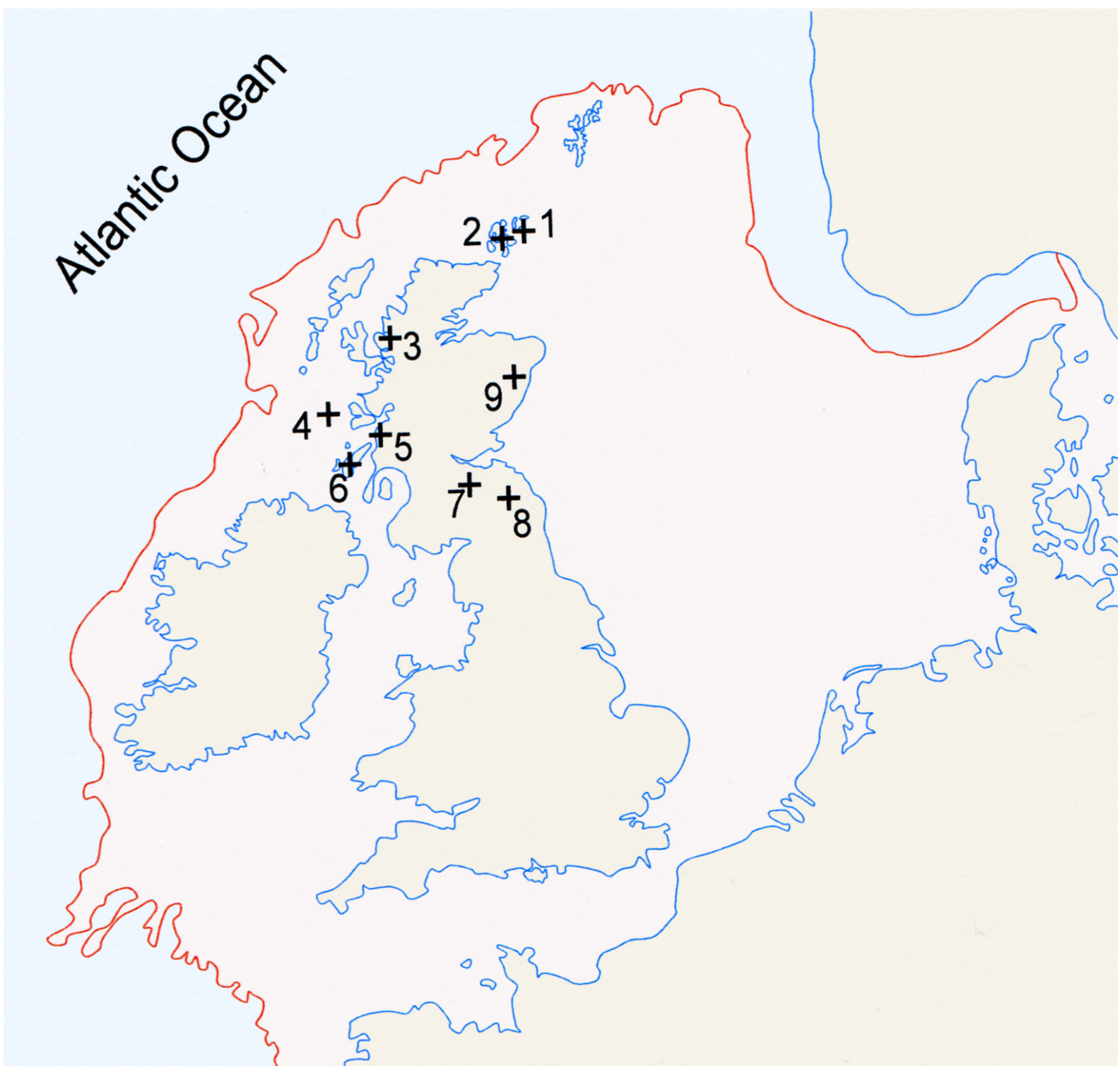

Figure 1. Map of find locations mentioned in the text in relation to the potential shores of Doggerland c. 16,000 BCE, after Spinney 2012 (drawn by TBB). The main Scottish sites of the Late Upper Palaeolithic period in the area are noted: 1) Millfield, Stronsay, Orkney and Links House, Stronsay, Orkney; 2) Brodgar, Mainland, Orkney; 3) Shieldaig, Loch Torridon; 4) Isle of Tiree, Inner Hebrides; 5) Kilmelfort Cave, Oban; 6) Rubha Port an t-Seilich on the Isle of Islay; 7) Howburn, South Lanarkshire; 8) Fairnington, Scottish Borders; 9) Nethermills Farm, Aberdeenshire. 
This paper presents the case study of a newly identified tanged point, as well as several likely other pre Mesolithic pieces, excavated between 1978 and 1981 at Nethermills Farm in Aberdeenshire, and suggests an approach for the continued search for the earliest settlers in Scotland after the retreat of the inland ice sheets, as well as for further investigation of the large Nethermills Farm assemblage. It should be emphasized that the focus of this paper is strictly Scottish, dealing with Scottish sites and finds, and the Continental material cultures to which they are affiliated. The north-west European industries dealt with in this paper are characterized, discussed and summarized in, inter alia, Terberger \& Eriksen (2004); Terberger (2006); Grimm \& Weber (2008); Grimm et al. (2012). Our comparison has focused mainly on research papers from northern Germany, and in particular papers from Centre for Baltic and Scandinavian Archaeology at Schloss Gottorf in Schleswig-Holstein, as 1) the main bulk of synthetic papers on the period in question has been produced by researchers from this and other northern German institutions; and 2) with southern British industries being of a Creswellian nature when Scotland was characterized by Hamburgian industries (Table 1), any contacts across Doggerland at that time, linking Scotland with the Continent, are likely to have been with the northernmost parts of Germany and Scandinavia, and not with more southerly parts of north-west Europe.

\section{The Nethermills Farm site and its excavation}

Nethermills Farm (Figure 2) was excavated by Kenworthy (1981) between 1978 and 1981, but post-excavation work on the site has only recently been undertaken, in 2013. A number of cut features were recorded (Figure 3), but it has not been possible to confirm the presence of structures here, despite Kenworthy's initial information. A wide spread of radiocarbon determinations was obtained, from the sixth millennium BCE to the first millennium BCE; considerable animal disturbance may have impacted on the integrity of the deposits (Wickham-Jones et al. in press). Excavation resulted in the recovery of approximately 30,000 lithic finds. Further work has been carried out at the location by local fieldwalkers, producing an additional c. 10,000 pieces (Wickham-Jones et al. in press). In the literature, the site and its finds are usually referred to as later Mesolithic, but recent detailed examination and analysis of the lithic assemblage has showed that although predominantly Mesolithic and narrow blade in nature, the lithics also include a notable broad blade element, a few later prehistoric pieces, and some material that appears to be pre-Mesolithic (Ballin 2013).

In line with Kenworthy's research interests and the exigencies of the time, the lithic finds from Nethermills were individually wrapped in paper before being bagged. This left the recent post-excavation analysis with a problem regarding the time and effort necessary to unwrap some 30,000 pieces, many of which comprised chips as small as a few millimetres across. In consequence, the 2013 analysis focussed on pieces originally identified by Kenworthy as 'specials' (cores and retouched pieces). These comprised 1670 pieces (Table 2) and spot checks suggested that, while some cores and retouched pieces may remain unrecognized, in general this sample would be representative of the whole assemblage. In all, a total of 2750 pieces were studied, roughly $9.1 \%$ of the whole collection. It should be emphasized that Nethermills Farm is a palimpsest, and the on-site provenance of the individual pieces did not allow the identification of LUP workshops or concentrations.

The potentially LUP pieces from Nethermills Farm are presented below and compared with similar pieces from published pre-Mesolithic assemblages from Scotland. 


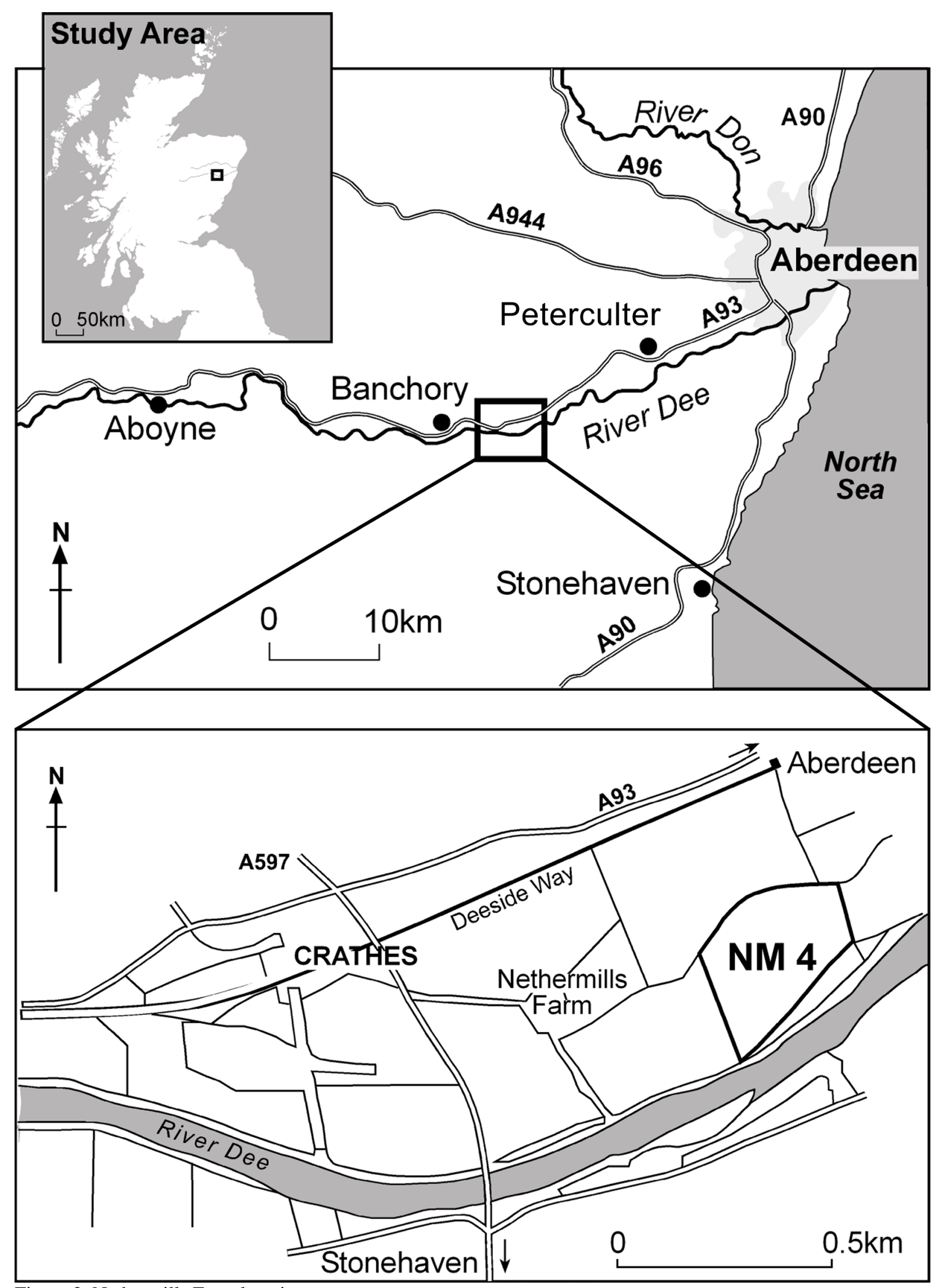

Figure 2. Nethermills Farm location map. 


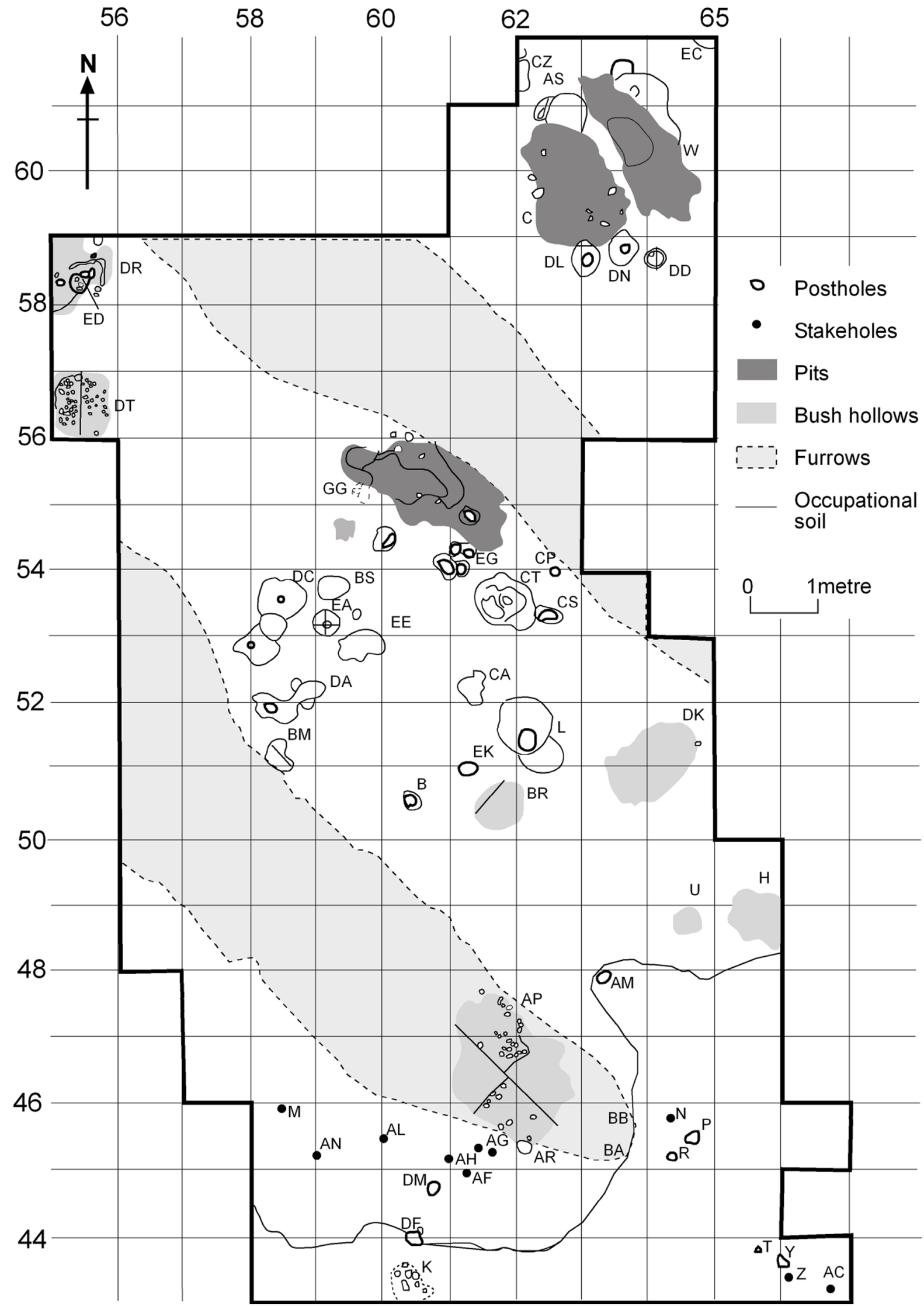

Figure 3. Nethermills Farm excavation plan. (Scale: 1 metre grid.) 
Table 2. The lithic cores and tools examined from Nethermills Farm (Kenworthy's 'specials').

\begin{tabular}{|c|c|c|c|}
\hline Artefact categories & Artefact sub-categories & Sub-totals & Totals \\
\hline \multicolumn{4}{|l|}{ Cores } \\
\hline Core rough-outs & & 3 & \\
\hline Conical cores & & 16 & \\
\hline Single-platform cores & & 54 & \\
\hline Opposed-platform cores & & 7 & \\
\hline Cores w two platfs at angle & & 3 & \\
\hline Irregular cores & & 6 & \\
\hline Atypical cores & & 1 & \\
\hline Bipolar cores & & 30 & \\
\hline Core fragments & & 7 & \\
\hline Total cores & & & 127 \\
\hline \multicolumn{4}{|l|}{ Tools } \\
\hline \multirow[t]{15}{*}{ Microliths and microlith-related } & Microlith preforms & 42 & 1,144 \\
\hline & Angle-backed and rhomboid pieces & 3 & \\
\hline & Obliquely blunted points & 21 & \\
\hline & Isosceles triangles & 6 & \\
\hline & Do., small & 2 & \\
\hline & Scalene triangles & 82 & \\
\hline & Quadrilaterals & 1 & \\
\hline & Crescents & 29 & \\
\hline & Edge-blunted pieces & 31 & \\
\hline & Idiosyncratic microliths & 5 & \\
\hline & Backed bladelets & 42 & \\
\hline & Truncated bladelets & 10 & \\
\hline & Frags of microliths & 70 & \\
\hline & Frags of microliths and backed bladelets & 180 & \\
\hline & Microburins & 620 & \\
\hline \multirow[t]{9}{*}{ Scrapers } & Discoidal scrapers & 1 & 81 \\
\hline & Blade-scrapers & 10 & \\
\hline & Short end-scrapers & 36 & \\
\hline & Thumbnail-scrapers (EBA) & 1 & \\
\hline & Double-scrapers & 3 & \\
\hline & Side-scrapers & 8 & \\
\hline & End- and side-scrapers & 11 & \\
\hline & Atypical scrapers & 3 & \\
\hline & Scraper-edge fragments & 8 & \\
\hline \multirow[t]{3}{*}{ Knives } & Backed blades & 3 & 48 \\
\hline & Truncated pieces & 44 & \\
\hline & Scale-flaked knives & 1 & \\
\hline \multirow[t]{2}{*}{ Piercers } & Large piercers & 8 & 25 \\
\hline & Meches de foret (drill tips) & 17 & \\
\hline \multirow[t]{2}{*}{ Burins } & Burins & 5 & 6 \\
\hline & Burin spalls & 1 & \\
\hline Combined tools & & & 2 \\
\hline \multirow[t]{3}{*}{ Various edge-modification } & Notched pieces & 39 & 232 \\
\hline & Pieces w edge-retouche & 192 & \\
\hline & Pieces $w$ invasive retouch & 1 & \\
\hline \multirow[t]{4}{*}{ Non-lithics, non-knapped lithics } & Stone beads & 1 & 5 \\
\hline & Hammerstones & 1 & \\
\hline & Pottery & 1 & \\
\hline & Glass beads & 2 & \\
\hline Total tools & & & 1,543 \\
\hline Total & & & 1,679 \\
\hline
\end{tabular}




\section{The assemblage from Nethermills Farm and its LUP elements}

The most well-known diagnostic forms from the north-west European LUP industries are tanged points, as well as some backed forms. In Scotland, tanged points are so far absent from stratified Mesolithic and later assemblages (Saville 2004), whereas some Scottish examples have been identified by local as well as Continental specialists as dating to the later Hamburgian (Howburn) and the Ahrensburgian (Tiree and Shieldaig), with Orcadian points showing Scandinavian affinities (Ballin \& Bjerck 2016).

The most likely LUP piece from Nethermills Farm is CAT 81/956, the medial fragment of a blade-based tanged point (Figure 4). While the base of the tang has broken off, as has the tip of the point, the piece is clearly the fragment of a point with an asymmetrical tang. Asymmetrical tangs such as this are usually associated with the late Hamburgian Havelte Phase (Grimm et al. 2012); most of the tangs recovered at Howburn are of this type (Figure $5)$.

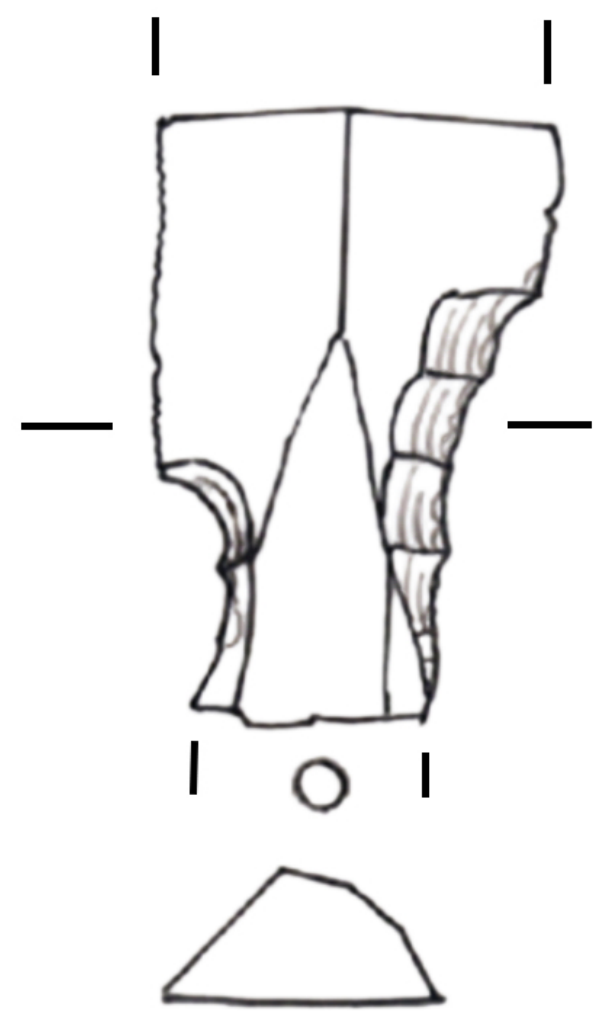

Figure 4. Tanged point fragment from Nethermills Farm (CAT 81/596: length 17 mm).

However, most (not all) of the tanged points from Howburn also have a notable lateral spur, and the tangs tend to be distal and shaped by 'propellar' retouch, whereas the tang of CAT 81/596 is proximal and formed by retouch from the ventral face. At present, it is therefore only possible to define this piece as the fragment of a tanged point of unspecified affiliation, but of likely LUP date.

The assemblage from Nethermills Farm also includes 40 truncated pieces, of which 18 have oblique truncations (e.g., CAT 78/019, Figure 6). Twenty-three of the truncated pieces are based on broad blades. It is not possible to date any of these pieces precisely, but Figure 6 shows the tip of a tanged point from Howburn, and pieces like these (from this and other sites) should be scrutinized as potential fragments of tanged points. However, CAT 78/019 is distal, whereas most (though not all) of the tanged points from Howburn have proximal tips. 


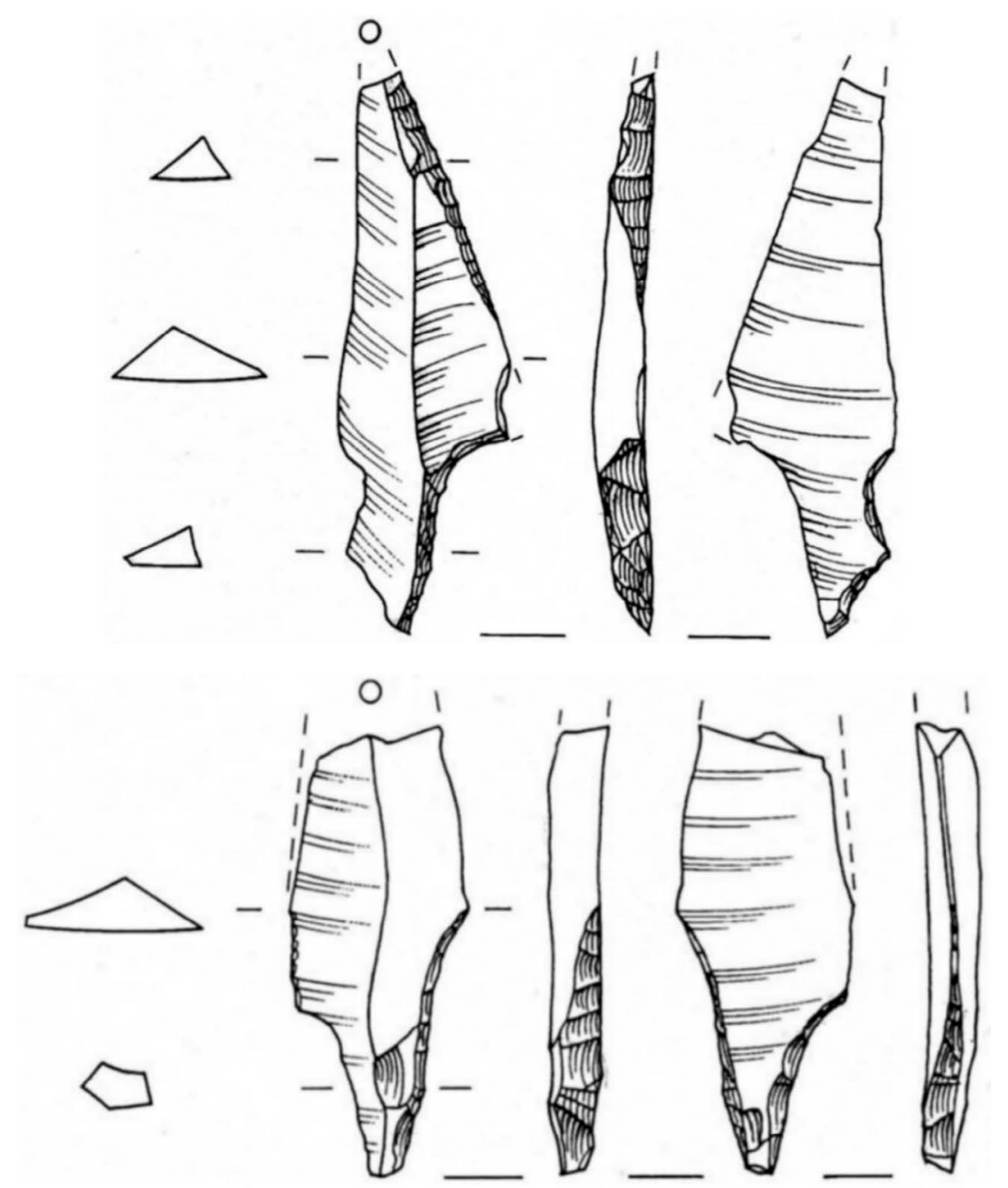

Figure 5. Two tanged points from Howburn (top: CAT 4041: length 42mm; bottom: CAT 1734: length 32 mm). Both points were recovered in connection with the second excavation on the site in 2009, and they will be discussed in Ballin et al. in press.
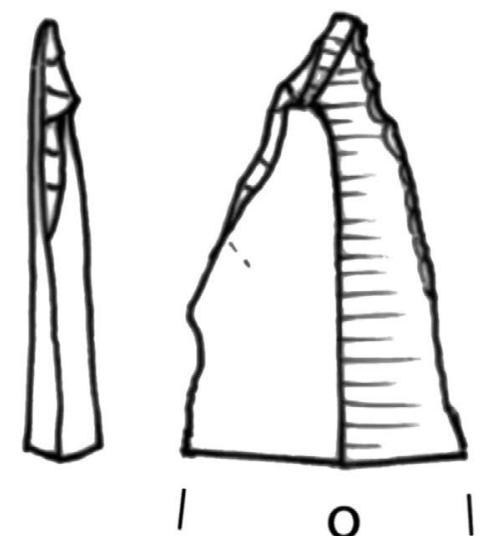
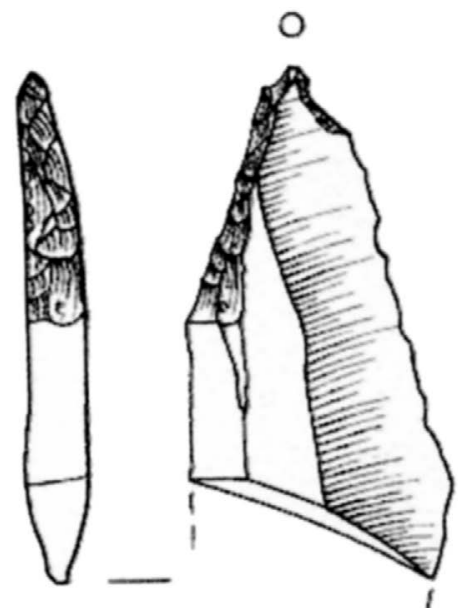

Figure 6. Left: A piece with oblique truncation from Nethermills Farm (CAT 78/019: length 21mm). Right: one from Howburn (CAT 795: length 36mm).

Also of interest are the scrapers. The assemblage at Nethermills Farm contained two blade-scrapers that closely parallel scraper types from Howburn. These long, regular, bladescrapers are very different to the relatively small oval specimens from the FedermesserGruppen site at Kilmelfort Cave, which resemble those to be found on Scottish Early 
Mesolithic sites (e.g., Morton A; Coles 1971: 307). Blade-scrapers such as these are wellknown from Star Carr in Yorkshire (Clark 1954: 40), but they are rare in Scottish Mesolithic contexts (Saville 2004). The two blade-scrapers from Nethermills Farm shown in Figure 7 are better parallels to the scrapers from Howburn than to scrapers from any later sites and CAT $78 / 123$ even has the acute working-edge which is so characteristic of many of the Hamburgian scrapers from South Lanarkshire (e.g., CAT 822; Figure 8).
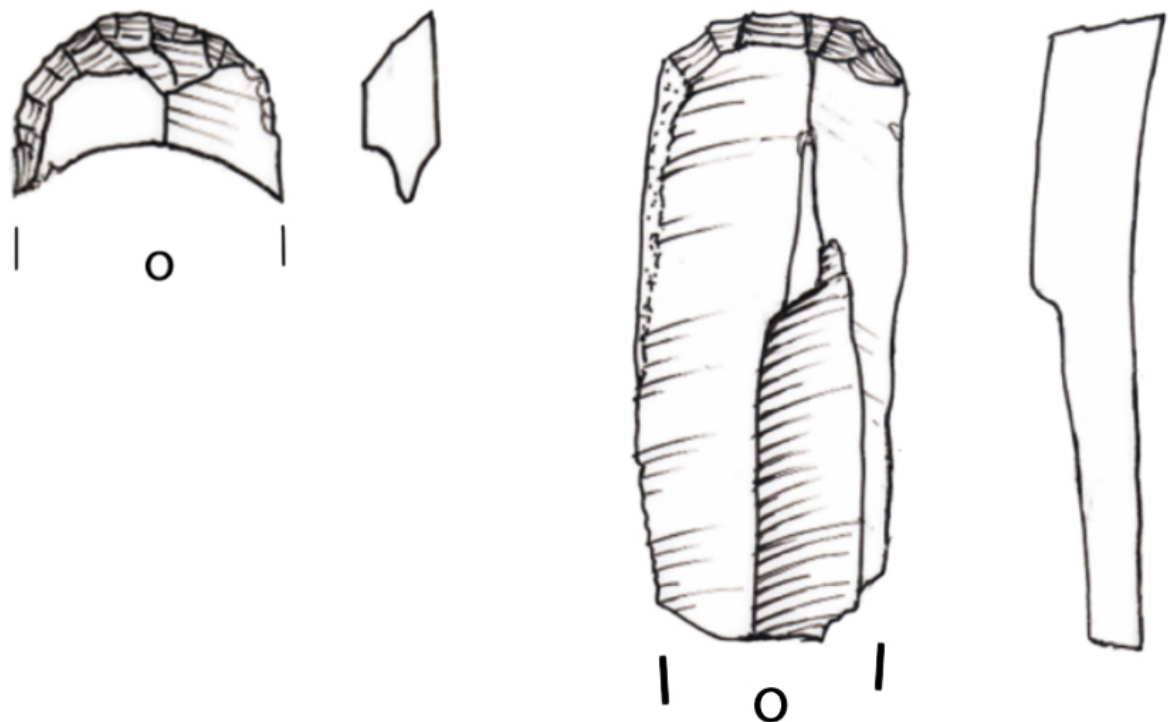

Figure 7. Two blade-scrapers from Nethermills Farm (left: CAT 78/123: length 9mm; right: CAT 79/404: length $40 \mathrm{~mm})$.
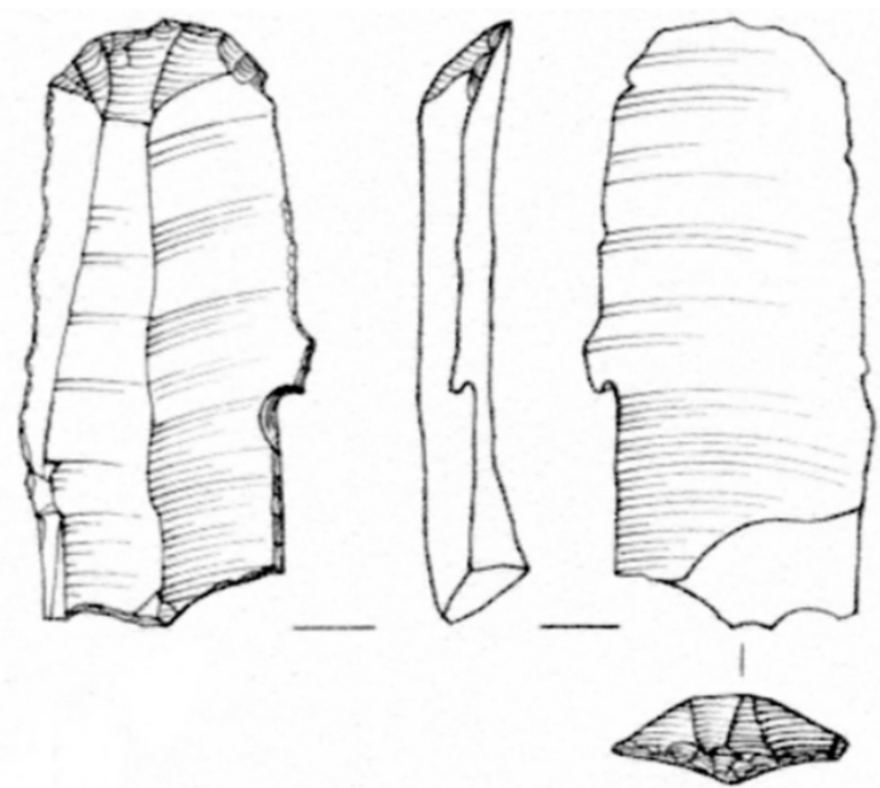

Figure 8. Blade-scraper from Howburn (CAT 822: length 38mm) with a typical acute scraper-edge and a proximal spur indicating the use of en eperon technique.

Finally, the Nethermills Farm assemblage also includes a number of angle-backed and rhomboid pieces (Figure 9) based on broad blades. Although it is possible that these pieces could be forms of broad blade Mesolithic microliths related to large isosceles triangles, anglebacked specimens have also been found at both Howburn and Kilmelfort Cave, and a piece from Fairnington, near Kelso, Scottish Borders is illustrated in Saville (2004: 213; although see comment above). These pieces would also have good Cresswellian parallels (Jacobi 2004) 
and given current uncertainties over the precise nature of Upper Palaeolithic technology and culture in Scotland we cannot rule out the possibility that Creswellian-style artefacts such as these might be present during an earlier Hamburgian phase, although with the growing evidence, this seems less and less likely.
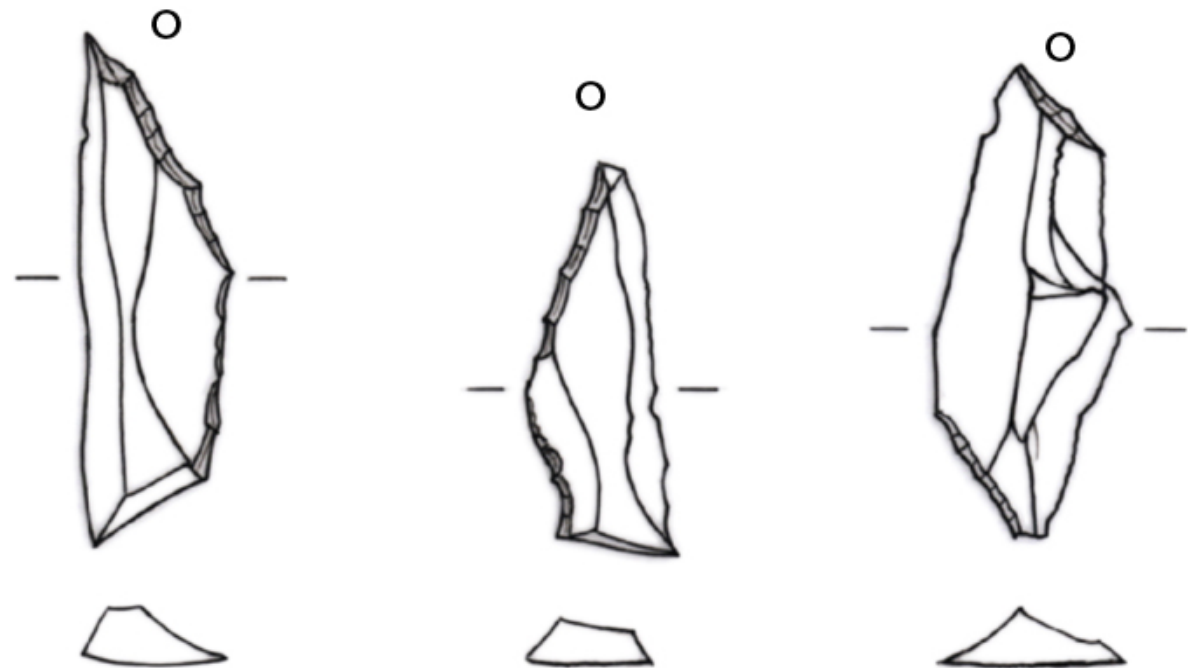

Figure 9. Angle-backed and rhomboid points from Nethermills Farm (CAT 78/802: length 26mm; 80/808: length 21mm; 79/354: length 25mm).

\section{Discussion}

In his paper 'Behavioral Archaeology and the Pompeii Premise', Binford (1981) reminded us that Pompeii-like sites are exceptionally rare, and that archaeological sites are usually heavily depleted snapshots of the past. In many cases, prehistoric sites do not include scientifically datable material, and in Scotland the earliest prehistoric sites to date are as a rule characterized by the presence of lithic artefacts and not much else. The paucity of material, so far, has cast doubt on the nature (or even existence), of pre-Mesolithic activity in Scotland but it is our contention that with finds of early affiliation increasing in number it is time to devote serious research to this period. Various taphonomic factors come into play such as the active geomorphological processes and dynamic palaeoenvironmental conditions of the Late Glacial and Early Holocene periods in Scotland, but with increased research comes the likelihood that better preserved material will be found. Two productive lines of work can serve to kick start investigation. Firstly, the recognition that new excavations may contain early elements: analysis of the lithic assemblages should include examination for known Palaeolithic type fossils. Secondly, many of the pieces may not be perfect type fossils and it is very possible that older collections include artefacts that have been overlooked. An examination of existing museum collections for tanged points and other elements is likely to be productive. Generally applicable elements of interest include detailed analysis of the raw materials, artefact types, and technological attributes (if possible, the full operational schema).

The highly mobile pre-Mesolithic groups of Scotland used both imported and local materials, including flint. The Howburn lithic assemblage, for example, is dominated by large flint implements which could not have been manufactured on the small pebbles that were locally available as coastal nodules. Furthermore, this flint is of a colour and quality not usually associated with southern Scotland and it is surmised to have come from sources such as Yorkshire (the closes source of in situ chalk flint; Ballin 2011) or Doggerland (Ballin 2016; Ballin \& Bjerck 2016). Less work has been undertaken elsewhere but analysis of raw materials should clearly be a priority. 
With regard to typology, work to date has focussed on a small number of type fossils that indicate LUP groups, but are of fairly general application. Tanged points and backed forms have been used to date both assemblages (Howburn and Kilmelfort Cave), and individual pieces (Tiree and Shieldaig), as of LUP affinity, but this links them to industries which are thought to have lasted up to 1,000 years each (the Hamburgian, Federmesser-Gruppen and Ahrensburgian periods). Other important types need to be considered, including bladescrapers with acutely angled working-edges, and Zinken (it should be noted that Zinken are present at Howburn but much less common than in contemporary north-west European assemblages; Ballin et al. 2010). In addition, burins, while usually perceived in Scotland as a distinctly Mesolithic type, are in fact rare on sites of this age, yet often occur in greater numbers in Scottish LUP assemblages. In this respect it is notable that in particular Howburn includes numerous burins, with burins on truncations being common. Finally, it is, of course, important to remember that perfect, complete artefacts are not, usually, the norm meaning that research has to consider the by-products of specific flaking techniques and artefact manufacture as well as broken and discarded pieces.

Technologically, the LUP industries of north-west Europe seem to be based on the production of large blades, which occasionally reach impressive proportions, and the existing evidence indicates that this holds good for their Scottish equivalents. The size of these blades indicates the importation of flint, most likely from Yorkshire or Doggerland. Most of these industries also share a preference for large opposed-platform cores, which may be flat or cylindrical (compare with core 828 from Howburn; Ballin et al. 2010; also Madsen 1992: fig. 81). The reduction technique seems to have been mainly soft percussion, occasionally associated with fine faceting of the platforms, and in the case of Howburn the use of en eperon technique. The latter leaves a small but notable spur at the platform-edge (Ballin et al. 2010: fig. 11), and this approach characterized the Hamburgian, the Creswellian, and the late Magdalenian industries (Weber [2012: fig. 23] shows an example of an en eperon blade from the Hamburgian site Teltwisch 1, Schleswig-Holstein, Germany). Whether or not it is possible to recognise specific regional developments in lithic technology remains to be seen but it should be remembered that not all pieces will necessarily follow Continental norms.

The fragments of a tanged point and blade-scrapers from Nethermills Farm are likely to be of LUP date. As we have noted, there are other pieces of probably pre-Mesolithic date from the site. The tanged point, nevertheless, is of particular interest, given the previous attention paid to these pieces as indicators of pre-Mesolithic activity in Scotland and their status in Scandinavia and north-west Europe as iconic markers that cross the Late Palaeolithic - Early Mesolithic divide. In this respect it is worth noting that the occurrence of a tanged point at Nethermills Farm extends the distribution of these pieces in Scotland to include the eastern valleys leading into the Cairngorms (where recent fieldwork has yielded archaeological material including broad blade lithics and dates that focus on the seventh millennium but extend back to around $8000 \mathrm{cal}$ BCE, Fraser et al. 2015). Although it is clear that Scottish tanged points include pieces of different affiliations and date, it is also clear that this is an artefact type that might be expected to occur across the country and with which archaeologists should now become more familiar.

Clearly one point of this paper is to encourage the search for lithic artefacts indicative of early human activity in Scotland. With this in mind, the remaining excavated assemblage from Nethermills Farm offers considerable potential for the recovery of further LUP material, both recognisable cores, tools and waste. This assemblage is just one, however, of many uncatalogued lithic collections carefully curated in museums across Scotland. We suggest that Palaeolithic material is highly likely to be hiding in museum collections throughout the country and that the (re)examination of existing lithic assemblages in the light of improved 
understanding of the likelihood of early artefacts should be a high priority for any new research agenda.

\section{Acknowledgements}

Post-excavation work at Nethermills Farm was funded by Historic Environment Scotland and co-ordinated by Gordon Noble. Marion O'Neill completed the lithic drawings and Figures 2 and 3 were produced by Jennifer Johnston. Writing this paper brings to mind a friend and colleague, Alan Saville, whose untimely death, while it was being prepared, has surely deprived us of many in-depth debates over tanged points. Finally we would also like to thank one anonymous and one named referee (Sonja Grimm, Schloss Gottorf, SchleswigHolstein, Germany) for their input, which improved and added relevant detail to the paper, as well as the editorial team at JLS whose comments were also gratefully received.

\section{References}

Ballin, T.B. 2011, Overhowden and Airhouse, Scottish Borders. Characterization and interpretation of two spectacular lithic assemblages from sites near the Overhowden Henge. British Archaeological Reports British Series Vol. 539. Archaeopress, Oxford. $74 \mathrm{p}$.

Ballin, T.B. (2013), The lithic assemblage from Nethermills Farm, Banchory, Aberdeenshire. Unpublished report, Aberdeen University, Aberdeen, 46 p.

Ballin, T.B. 2016, Rising waters and processes of material cultural diversification and unification - the flooding of Doggerland and its effect on NW European prehistoric populations between c. 13,000 and 1,500 cal BC. Journal of Quaternery Science, 32(2): 329-339. doi:10.1002/jqs.2834

Ballin, T.B., \& Bjerck, H.B. 2016, Lost and found twice: Discussion of an early post-glacial single-edged tanged point from Brodgar on Orkney, Scotland. Journal of Lithic Studies, 3(1): 31-50. doi:10.2218/jls.v3i1.1393

Ballin, T.B. \& Saville, A. 2003, An Ahrensburgian-type tanged point from Shieldaig, Wester Ross, Scotland, and its implications. Oxford Journal of Archaeology, 22(2): 115-131. doi:10.1111/1468-0092.t01-1-00001

Ballin, T.B., Saville, A., Tipping, R., \& Ward, T. 2010, An Upper Palaeolithic Flint and Chert Assemblage from Howburn Farm, South Lanarkshire, Scotland: First Results. Oxford Journal of Archaeology, 29(4): 323-360. doi:10.1111/j.1468-0092.2010.00352.x

Ballin, T.B., Saville, A., Tipping, R., Ward, T., \& Housley, R. in press: A Late Upper Palaeolithic (Late Hamburgian) settlement in southern Scotland: the artefactual evidence from Howburn Farm, South Lanarkshire. Archaeopress, Oxford.

Clark, J.G.D. 1954, Excavations at Starr Carr. An Early Mesolithic Site at Seamer near Scarborough, Yorkshire. Cambridge University Press, Cambridge, 200 p.

Coles, J.M. 1971, The Early Settlement of Scotland: Excavations at Morton, Fife. Proceedings of the Prehistoric Society, 37: 284-366. doi:10.1017/S0079497X00012688

Fitch, S., Gaffney, V. \& Thomson, K. 2007, In Sight of Doggerland: From speculative survey to landscape exploration. Internet Archaeology, 22. Retrieved 09 March 2017. doi:10.11141/ia.22.3 
Fraser, S.M., Noble, G., Warren G. \& Wickham-Jones C.R. 2015, Upper Dee Tributaries Project. Discovery and Excavation in Scotland, 2015: 15-16.

Grimm, S.B. \& Weber, M.-J. 2008: The chronological framework of the Hamburgian in the light of old and new 14C dates. Quartär, 55: 17-40. doi:10.7485/QU55_02

Grimm, S., Skov Jensen, D. \& Weber, M.-J. 2012, A lot of good points - Havelte points in the context of Late Glacial tanged points in Northwestern Europe. In: A mind set on flint. Studies in honour of Dick Stapert (M.J.L.T. Niekus, R.N.E. Barton, M. Street \& T. Terberger, Eds.), Groningen Archaeological Studies 16. Groningen Institute of Archaeology, Groningen: p. 251-266.

Jacobi, R.M. 2004, The Late Upper Palaeolithic Lithic Collection from Gough's Cave, Cheddar, Somerset, and Human Use of the Cave. Proceedings of the Prehistoric Society, 70: 1-92. doi:10.1017/S0079497X00001110

Livens, R.G. 1956, Three tanged flint points from Scotland. Proceedings of the Society of Antiquaries of Scotland, 89: 438-43. doi:10.5284/1000184

Madsen, B. 1992, Hamburgkulturens flintteknologi i Jels. In: Istidsjægere ved Jelssøerne. Hamburgkulturen i Danmark (J. Holm \& F. Rieck). Skrifter fra Museumsrådet for Sønderjyllands Amt Vol. 5. Haderslev Museum, Haderslev: p. 93-131. (in Danish, summary in English) ("The flint technology of the Hamburgian sites at Jels" In: Ice Age hunters by the Jels Lakes and the Danish Hamburgian”)

Mithen, S., Wicks, K., Pirie, A., Riede, F., Lane, C., Banjera, V., Cullen, V., Gittins, M. \& Pankhurst, N. 2015, A Lateglacial archaeological site in the far north-west.of Europe at Rubha Port an t-Seilich, Isle of Islay, western Scotland: Ahrensburrgain-style artefacts, absolute dating and geoarchaeology, Journal of Quaternary Science, 30 (5): 396-416. doi:10.1002/jqs.2781

Pettitt, P. 2008: The British Upper Palaeolithic. In: Prehistoric Britain (J. Pollard, Ed.). Blackwell Studies in Global Archaeology, Blackwell Publishing, Malden (MA): p. 1857.

Pettitt, P. \& White, M. 2012: The British Palaeolithic. Hominin societies at the edge of the Pleistocene world. Routledge Archaeology of Northern Europe, Routledge, London, $592 \mathrm{p}$.

Saville, A. 2004, The Material Culture of Mesolithic Scotland. In: Mesolithic Scotland and its Neighbours. The Early Holocene Prehistory of Scotland, its British and Irish Context, and some Northern European Perspectives (A. Saville, ed.). Society of Antiquaries of Scotland, Edinburgh: p. 185-220.

Saville, A. 2008, The beginning of the later Mesolithic in Scotland. In: Man - Millennia Environment: Studies in Honour of Romuald Schild (Sulgostowska, Z. \& Tomaszewski, A.J., Eds.). Polish Academy of Sciences Institute of Archaeology and Ethnology, Warsaw: p. 207-213.

Saville, A., \& Ballin, T.B. 2009, Upper Palaeolithic evidence from Kilmelfort Cave, Argyll: A re-evaluation of the lithic assemblage. Proceedings of the Society of Antiquaries of Scotland, 139, 9-45. doi:10.5284/1000184

Spinney L. 2012, The lost world of Doggerland. National Geographic, 222: 132-143. 
Sturt, F., Garrow, D., \& Bradley, S. 2013, New models of north-west European paleogeography and inundation. Journal of Archaeological Science, 40(11): 3963-76. doi:10.1016/j.jas.2013.05.023

Terberger, T. 2006, From the First Humans to the Mesolithic Hunters in the Northern German Lowlands - Current Results and Trends. In: Across the western Baltic (K. Møller Hansen \& Buck Pedersen, K., Eds.). Sydsjællands Museums Publikationer Vol. 1. Sydsjællands Museum, Vordingborg: p. 23-56.

Terberger, T. \& Eriksen, B.V. (Eds.) 2004, Hunters in a Changing World. Environment and Archaeology of the Pleistocene - Holocene Transition (c. 11000 - 9000 B.C.) in Northern Central Europe. Workshop of the U.I.S.P.P.-Commission XXXII at Greifswald in September 2002. Internationale Archäologie, Bd. 5. Verlag Marie Leidorf GmbH, Rahden/Westf., 270 p.

Weber, M.-J. 2012, From technology to tradition - Re-evaluating the HamburgianMagdalenian relationship. Untersuchungen und Materialien zur Steinzeit in SchleswigHolstein und im Ostseeraum Vol. 5. Wachholtz, Neumünster, 252 p.

Wickham-Jones C.R., Kenworthy J.B., Gould, A. MacGregor G. \& Noble G. in press, Archaeological Excavations at Nethermills Farm, Deeside, 1978-81. Proceedings of the Society of Antiquaries of Scotland, 146: 46 p. 